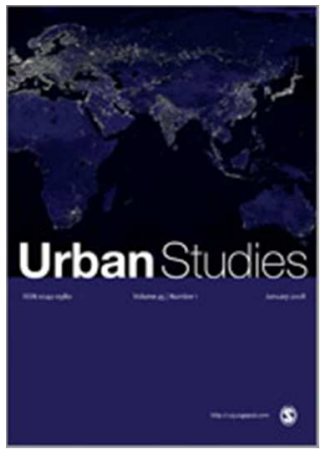

\title{
The Impact of Income Inequality on Rental Affordability: An Empirical Study in Large American Metropolitan Areas
}

\section{Dr. Hongwei Dong, Department of Geography and City \& Regional Planning, California State University, Fresno.}

\begin{tabular}{|c|c|}
\hline Journal: & Urban Studies \\
\hline Manuscript ID & CUS-901-16-10.R1 \\
\hline Manuscript Type: & Article \\
\hline $\begin{array}{r}<\text { b }>\text { Discipline: Please select a } \\
\text { keyword from the following list } \\
\text { that best describes the } \\
\text { discipline used in your paper.: }\end{array}$ & Economics \\
\hline $\begin{array}{r}\text { World Region: Please select } \\
\text { the region(s) that best reflect } \\
\text { the focus of your paper. } \\
\text { Names of individual countries, } \\
\text { cities \& economic groupings } \\
\text { should appear in the title } \\
\text { where appropriate.: }\end{array}$ & North America \\
\hline $\begin{array}{l}\text { Major Topic: Please identify up } \\
\text { to two topics that best identify } \\
\text { the subject of your article.: }\end{array}$ & Housing \\
\hline $\begin{array}{r}\text { Please supply a further } 5 \\
\text { relevant keywords in the fields } \\
\text { below: : }\end{array}$ & $\begin{array}{l}\text { income inequality, housing affordability, housing equity, low-income } \\
\text { tenants, rent burden }\end{array}$ \\
\hline
\end{tabular}

Please cite this article as: "Dong, H. (2017). The impact of income inequality on rental affordability: An empirical study in large American metropolitan areas. Advance online publication. DOI: https:// doi.org/10.1177/0042098017710380 


\title{
The Impact of Income Inequality on Rental Affordability: An Empirical Study in Large American Metropolitan Areas
}

\begin{abstract}
:
American metropolitan areas have experienced rising income inequality and worsening rental affordability in the past few decades. Has the rise of inequality caused worsening rental affordability? This study conducts both cross-sectional and longitudinal analyses to examine the impact of income inequality on rental affordability for low-income tenant households at the county level in America's largest 100 metropolitan areas. The cross-sectional analyses reveal that, everything else equal, an increase of Gini coefficient by 0.1 in a county was associated with 2.2 and 4.4 percentage points more severely rent-burdened low-income households in 2000 and 2008-2012 respectively. The longitudinal analyses confirm that rising income inequality caused worsening rental affordability for low-income tenant households in large American metropolitan areas between 2000 and 2008-2012. On average, counties that experienced a 0.1 greater increase in Gini coefficient from 2000 to 2008-2012 saw faster growth of severely rent-burdened lowincome tenant households by 2.9 percentage points.
\end{abstract}

Keywords: income inequality, housing affordability, housing equity; rent burden; low-income tenants 


\section{Introduction}

It is a well-known fact that income inequalities in the United States have increased dramatically in the past few decades (Attanasio, Hurst, and Pistaferri, 2012; Piketty and Saez, 2006). The level of inequality in the United States today, for both market income and disposable income, is greater than at any point in the past 40 years (McCall, 2012). Large metropolitan areas and their big cities tend to be more unequal than the rest of the country: in 2003 , households in the $95^{\text {th }}$ percentile of income in the largest 50 cities earned 11.6 times as much as households at the $20^{\text {th }}$ percentile, much wider than the national average ratio of 9.3 (Berube and Holmes, 2015\&2016).

Concurrently, housing affordability in the United States has significantly declined, especially for low-income tenants in large metropolitan areas. My calculation based on the Comprehensive Housing Affordability Strategy (CHAS) Database shows that about 39\% of low-income tenant households in the largest 100 American metropolitan areas paid more than $50 \%$ of their incomes for rent in 2008-2012, about 10 percentage points higher than the rate in 2000 (39\% vs. 29\%). Rent burden is particularly acute for low-income tenants in large metropolitan areas in Florida and California, where $44 \%$ of them paid more than $50 \%$ of their incomes for rent in $2008-2012$ (34\% in 2000). The prevalence of very high rent burdens is an important area for urban policy. When people spend such a very large share of income on housing, it is extremely difficult for them to satisfy other essential needs for food, health care, transportation, child care, and education (Arnold and Skaburskis, 1989; Bunting, Walks, and Filion, 2004). Declining housing affordability is also widely believed to be an important factor that leads to the homeless problem plaguing many American cities (Bunting, Walks, and Filion, 2004). 
Figure 1 illustrates the correlations between income inequality (represented by Gini Coefficient) and the rate of severe rent burdens among low-income households at the county level within the largest 100 American metropolitan areas. The top graph shows that income inequality is significantly and positively correlated with severe rent burdens among low-income households in both 2000 and 2008-2012. The bottom graph indicates that rising income inequalities between 2000 and 2008-2012 are significantly and positively correlated with worsening rental burdens among low-income households in that period.

[Figure 1 about here]

Has rising income inequality caused worsening rental affordability in American metropolitan areas? The aim of this study is to answer this question. The focus is on low-income tenant households in the top 100 large American metropolitan areas because it is far more common for low-income tenant households in large cities to encounter housing affordability difficulties. In order to detect the effect of inequality on rental affordability, I first develop two sets of crosssectional models to evaluate their associations in 2000 and 2008-2012 respectively by controlling for many other relevant variables. I then conduct longitudinal analyses to assess whether rising income inequality has caused worsening rental affordability in America's largest 100 metropolitan areas between 2000 and 2008-2012.

The study contributes to the literature in several ways. To my best knowledge, this is one of the few studies that evaluate the impact of rising income inequality on worsening rental affordability in the 2000s, a period in which both inequalities and rent burdens increased dramatically in large American metropolitan areas. Unlike previous studies that rely on cross-sectional analyses, this study develops both cross-sectional and longitudinal models to assess the impact of inequality on 
affordability. Longitudinal analysis allows us to establish sequences of events and to capture the net effect changes. Longitudinal study is also less vulnerable than cross-sectional modeling to omitted variable and selection bias issues. Furthermore, this study explicitly examines the potential endogeneity problem in modeling the relationship between income inequality and housing affordability, an issue that was largely ignored in previous studies.

The rest of the paper is organized as follows. The second section reviews previous studies that link income inequality to housing affordability as well as extant studies that examine demandand supply-side factors that potentially influence rental affordability. The third section introduces data sources, variables, and modeling approaches. The modeling results are reported in the fourth section. The fifth section draws final conclusions and discusses policy implications.

\section{Literature Review}

In this section, I first review prior studies that have examined demand and supply factors that influence home affordability. I then focus on the studies that have explicitly tested the potential role of income inequality in reducing home affordability.

\section{Potential Drivers of home unaffordability in American Cities}

Numerous studies have shown that household demographic variables can determine the extent to which individual households are burdened by housing cost. The importance of income seems obvious. One can reasonably expect that lower-income households are more likely to be burdened by housing cost than higher-income households. Since the 1980s, there has been a rise of a phenomenon that is referred to as "new poverty" which is distinguished by demographic shifts toward the youthfulness of the population, higher underemployment rates, and more female-headed and single-parent households (Bunting, Walks, and Filion, 2004). Renter incomes 
have largely remained flat or declined in real terms during the past two decades in the United States (Collinson, 2011), while housing prices have been growing steadily in many American cities (S\&P Dow Jones Indices LLC, 2017). It is thus not surprising to see steadily declining home affordability in the United States, particularly in those superstar cities.

In addition to stagnant renter income and rising rents, basic demographic changes in American cities may also have caused the increasing prevalence of housing burdens. Such changes include the trends toward smaller households, more nonfamily households, the aging of the population, greater ethnic diversity, international and domestic immigration, and differential fertility rates (Moore and Skaburskis, 2004; Skaburskis, 2004; Withers, 1997). Minority households are doubly disadvantaged in urban housing markets because of the discriminatory practices in both the labor markets and the housing markets (Withers, 1997). The 2009 Worst Case Housing Needs Report issued by the U.S. Department of Housing and Urban Development (HUD) indicates that in 2009, non-Hispanic Black and Hispanic renters each represented around 23\% of renters burdened with worst case needs, higher than their proportions in the U.S. population (HUD, 2011). Withers (1997) examined the link between race and income in determining housing affordability in six representative American metropolitan areas, finding that an income effect existed regardless of race, but the race effect disappeared after controlling for income except for poor Black Households. Immigrant inflows can also increase rent burdens in a city by expanding population growth, increasing local housing demand, and influencing the local labor market (Moos and Skaburskis, 2010). It is estimated that an immigration inflow equal to $1 \%$ of a city's population is associated with an increase in average rents and housing values of about $1 \%$ (Saiz, 2007). 
Recent studies on fast-growing housing prices and worsening affordability in large American metropolitan areas have shifted their focus to the supply side of the market, particularly housing supply constraints caused by land use regulations. If housing markets were operating perfectly, there could be no such a thing as an affordability problem because the market could response to the change in housing demand and re-establish expenditure/income ratio (Moore and Skaburskis, 2004). However, in the real world, a housing market may not be able to respond to the changes in housing demand because of the existence of land use regulations (Glaeser and Gyourko, 2003; Glaeser et al., 2005a and 2005b; Gyourko, Mayer, and Sinai, 2013). An increasing number of empirical studies have shown that stringent land use controls substantially reduce housing supply elasticities and raise housing prices in local markets (Green, Malpezzi, and Mayo, 2005; Ihlanfeldt, 2007; Paciorek, 2013). Business leaders, developers, and recently, the media, housing activists, and White House economists have repeatedly claimed that zoning restrictions are a principal cause of constrained supply, and the removal of regulatory barriers would effectively improve housing affordability in American metropolitan areas (Beitel, 2007; Dougherty, 2016; Kirkham, 2016; Peters, 2016; Timiraos, 2015).

\section{How Might Income Inequality Influence Housing Affordability}

Since housing affordability is determined by both housing costs and incomes, trends in the distribution of income are potentially important in explaining the worsening housing affordability experienced by poor and near-poor households (Quigley and Raphael, 2004). Dewilde and Lancee (2013) conjecture three potential mechanisms through which income inequality might influence housing affordability: 1) the absolute level of resources, 2) conspicuous housing consumption, and 3) negative trickle-down in the housing market. 
Dewilde and Lancee (2013) argue that for countries with similar average incomes, the absolute level of resources held by those at the bottom of the income distribution is lower in more unequal countries than in countries with a more equal income distribution. The same can be said of the income distribution in American cities. In the past two decades, benefits from income growth failed to reach most of the population in the United States (Greenwood and Holt, 2010). Renter incomes have largely remained flat or declined in real terms in most American metropolitan areas and income polarization has produced increased numbers of individuals and households living under or slightly above the poverty line (Bunting, Walks, and Filion, 2004; Collinson, 2011). Apparently, slow income growth plus fast-rising rents can directly cause worsening rental affordability.

High consumer spending of the top income earners could inspire conspicuous housing consumption, which refers to the display of wealth through over-consumption of housing to signal success (Dewilde and Lancee, 2013; Greenwood and Holt, 2010). Housing is the largest single expense for most American households and homeownership is an essential part of the American dream. In addition to satisfying people's basic shelter needs, housing is a positional good whose utility is largely derived from the message it sends about the individual (Frank, 2007; Greenwood and Holt, 2010). In order to keep up with the rising housing standards inspired by the top income earners, low- and moderate-income households have to spend higher proportions of their incomes on housing and cut corners on the quantity and quality of other privately consumed goods (Greenwood and Holt, 2010).

High income inequality might also influence home affordability by distorting the dynamics of the housing market (Dewilde and Lancee, 2013). In a market economy, new housing construction is concentrated at the higher end of the market. Low-quality and low-cost housing is 
mainly supplied indirectly through filtering (Quigley and Raphael, 2004). Filtering is a process by which the nominal rent or price of a dwelling declines over time due to physical deterioration and functional obsolescence (Skaburskis, 2006). If filtering works effectively in a housing market, the supply at the higher end of the market may also enhance the available stock of lowcost housing by accelerating the downward filtering of existing housing to lower-income occupants (Malpezzi and Green, 1996). A study in Canada, however, suggests that filtering is both too slow and its effect is too small for reducing burdens of low-income people (Skaburskis, 2006). Skaburskis (2006) actually finds that negative trickle-down is at work in Canadian metropolitan housing markets because of gentrification. Beitel (2007) shows that housing prices in some hot markets display a fluid upward, sticky downward nature due to housing supply constraints. Even worse is that sustained rises in housing prices in the luxury sector may generate spill-over effects into the ordinary segment when developers begin to speculate on the redevelopment of old housing in this sector (Beitel, 2007).

Empirical studies that directly evaluate the effect of income inequality on home affordability are still scant. There are a handful of exceptions. Using data at the individual household level, Matlack and Vigdor (2008) examine the empirical association between rising income inequality and housing consumption of the poor (defined as households headed by a high school dropout) in the United States between 1970 and 2000. Their study shows that inequality is not universally associated with greater housing burden or reduced housing consumption by the poor and the impacts of inequality on low-income households' housing burden and consumption are concentrated in metropolitan areas with constrained housing supply. Dewilde and Lancee (2013) use the data from 28 European countries to analyze the relationship between income inequality and access to housing for low-income households at the market rate in Europe. Their analyses 
show that higher income inequality increases the likelihood of affordability problems and lowers housing quality for low income renters who pay market rates.

This study adds some recent evidence of the impact of inequality on housing affordability. Unlike previous studies that rely on cross-sectional analyses, this study develops both crosssectional and longitudinal models to assess the role of inequality in worsening rental affordability in America's largest 100 metropolitan areas. In addition, we directly examine the potential endogeneity problem in modeling the relationship between income inequalities and housing affordability, which was largely ignored in previous studies.

\section{Data, Variables, and Methods}

\section{Data Sources}

This study draws data from the Comprehensive Housing Affordability Strategy (CHAS)

Database to measure rental affordability. The U.S. Department of Housing and Urban

Development (HUD) periodically receives "custom tabulations" of data from the U.S. Census

Bureau that are largely not available through standard Census products. The CHAS data are used by local governments to plan how to spend HUD funds, and may also be used by HUD to distribute grant funds. Importantly, the CHAS Database demonstrates the extent of housing problems and housing needs of low-income tenant households that are defined based on a measure of "area median income (AMI)", enabling consistent measurement and comparisons of rent burdens among low-income tenants at different time points. In this study, we use CHAS 2000 and 2008-2012 data. The CHAS 2008-2012 data are the most recent CHAS data that are available at the time of writing. To develop explanatory variables, we also compile data from 
Census 2000 and the American Community Survey (ACS) 2008-2012 and match them with the affordability data from the CHAS Database.

\section{Study Context and Spatial Unit}

This study focuses on counties in America's largest 100 metropolitan statistical areas (hereafter refer to as "metropolitan areas"), which are selected by their populations in 2010. As of 2010, the top 100 metropolitan areas are home to $65 \%$ of the U.S. population. The sizes of these 100 metropolitan areas vary widely. The New York-Northern New Jersey-Long Island, the largest metropolitan area in the United States, has about 18.9 million people. Population in the smallest one among these 100 metropolitan areas, Lancaster, PA, is 0.52 million. Even though housing affordability is a pressing issue throughout the United States, households with extreme levels of affordability burdens concentrate in these large metropolitan areas, particularly their large cities (Withers, 1997).

We choose counties rather than metropolitan areas as analysis units because the boundaries of counties were stable in our study period, allowing us to make consistent longitudinal comparisons between the two time points (2000 vs. 2008-2012). The United States Census Bureau adjusted the boundaries of the American metropolitan areas in 2003, making Census data at the metropolitan level not directly comparable between the two time points. In Census 2010 , the largest 100 metropolitan areas contain a total of 573 counties. I have to remove three counties (Goochland County and King and Queen County in Virginia and Broomfield County in Colorado) due to missing variables. As will be discussed later, this analysis relies on the ACS three-year data (ACS 2005-2007 and ACS 2009-2011) to measure and control for the depth of the 2008 housing recession in each county. I thus have to drop 63 counties whose populations were below 
20,000 during the two ACS periods because they were not included in the two three-year ACS dataset. As a result, I am able to use $88 \%$ (507 out of 573) of the counties in the largest 100 American metropolitan areas (measured by their population in 2010) for modeling analyses. Descriptive statistics of the 507 counties are presented in Table 1.

[Table 1 about here]

\section{Measuring Rent Burdens for Low-Income Tenants}

The CHAS data use the standard rent-income ratio approach to measuring rent burdens. The rental costs component includes utilities and related shelter costs as well as rent. The CHAS tabulations use adjusted household income, which includes the income of all members of the household at the time of survey. The rent-income ratio approach has the advantage of being easy to calculate and to comprehend. It is widely used by landlords and lenders to make sure prospective tenants and borrowers will pay their rent and mortgage. HUD's Section 8 Housing Choice Voucher program also adopts the rent-income ratio method to determine one's rent burden.

The rent-income ratio measurement has its limitations. It does not differentiate between highincome renters who choose to spend large proportions of their income on rent as a life style choice and low-income households who are forced to spend large proportions of their income on rent (Baker, 2015; Skaburskis, 2006; Stone, 2006). It also does not take into account differences in housing and neighborhood quality as well as the actual financial constraints faced by individual households (Bogdon and Can, 1997).

Recognizing the limitations of the rent-income ratio approach, I focus my analyses on tenant households that: 1) had low-incomes, defined as earning less than $80 \%$ of AMI (area median 
income); and 2) suffered severe cost burdens, defined as paying over $50 \%$ of income for rent. Under current law, households with incomes below $80 \%$ of the AMI adjusted for household composition are eligible for rental housing subsidies. Compared with medium- and high-income households, low-income households are much less likely to spend large proportions of their income on rent as a life style choice. Due to supply constraints, low-income households have little flexibility to change the amount and quality of the available housing service to consume (Arnold and Skaburskis, 1989). The large percentage of low-income tenants that suffer severe rent burdens is a major policy concern because when low-income tenants devote very large shares of their incomes to housing, it is extremely difficult for them to satisfy other essential needs for food, health care, transportation, and education (Bunting, Walks, and Filion, 2004). HUD's 2011 Worst Case Housing Needs Report shows that "the vast majority of renters had worst case needs because of their severe rent burdens - paying more than half of their income for rent—while inadequate housing caused only three percent of worst case needs" (HUD, 2013).

As Table 1 shows, the average severe rent burden rate among the 507 studied counties was $24 \%$ in 2000 , meaning that on average about $24 \%$ of low-income tenant households paid more $50 \%$ of their income for rent. In 2008-2012, that number increased by about 11 percentage points to $35 \%$. In 2008-2012, the most severely rent-burdened county is Orange County, Florida, where 53\% of low-income tenant households paid more than $50 \%$ of their income for rent.

\section{Explanatory Variable}

The aim of this paper is to explain worsening rental affordability in large American metropolitan areas since 2000. I am particularly interested in the role of income inequality. I use Gini coefficients in 2000 and 2008-2012 at the county level to measure income inequalities. The Gini 
index of income inequality measures the dispersion of household income distribution. It ranges from zero (indicating perfect equality) to one (perfect inequality). In 2000, the average Gini coefficient among the 507 studied counties was 0.42 and it increased to 0.43 in 2008-2012. The county with the highest Gini coefficient in both 2000 and 2008-2012 was New York County, New York with a Gini coefficient of 0.60 .

According to literature, I develop a series of control variables that previous studied have found significant effects on rental affordability. On the demand side, I first consider household income and rent, which apparently influence rental burden (Bogdon and Can, 1997; Bunting, Walks, and Filion, 2004; Collinson, 2011; Quigley and Raphael, 2004). However, the inclusion of these two variables on the right hand of the equation may cause serious endogenous problems because these two factors are also included in rent-income ratio on the left side of the equation. In order to mitigate the potential endogeneity problem, I decide to use median household income and median rent for all the households in each county, not the income of low-income tenants and the amount of rent they pay. As will be discussed later in this article, only the median rent of each county is included in the final models because median income and median rent at the county level are highly correlated and median rent exhibits a stronger influence on rental burden for low-income tenement households. Dropping median household income from the model also helps to address the endogeneity concern.

I also control for a series of demographic variables of each county. As discussed in the Literature Review section, home affordability in a place might also be determined by demographic factors such as age structure, family size, minority population, unemployment rate, poverty, and immigrants (HUD, 2011; Moore and Skaburskis, 2004; Skaburskis, 2004; Withers, 1997; Saiz, 2007; Withers, 1997). I calculate the shares of Generation Y (population aged 25-34) and baby- 
boomers (aged 55 or more) in each county's population to represent the age structure of the population. I measure the share of households with 1-2 persons to represent the effect of smallsized households. The shares of non-Hispanic Blacks and Hispanics are used to represent the effect of minority population. I calculate the proportion of international immigrants that entered the United States within the past 10 years to represent the effect of immigrant inflows. I use unemployment rates in each county to represent local economic conditions and I include poverty rates to control for the proportions of low-income households in each county.

A part of the study period was in the 2008 economic recession which might exert influences on both rental rates and income distribution. I control for the effect of the housing recession by calculating a ratio between median home values before and after 2008 in each county. Specifically, I use the median home value in each county reported in the ACS 2005-2007 to represent housing prices before the recession. I then use the median home value in each county reported in the ACS 2009-2011 to represent housing prices in the recession. Because the threeyear ACS data only report median home values in counties with more than 20,000 people, I have to drop the counties whose populations were less than 20,000 during the two ACS periods from my modeling analysis. In addition, I use county population to represent housing demand in a local market.

On the supply side, following Matlack and Vigdor (2008), I calculate rental vacancy rate in each county to provide a measure of the difficulty households might face finding units affordable to them. I also calculate a ratio between the growth of median rent and the growth of rental units in each county from 2000 to $2008-2012$ as a proxy for rental housing supply elasticity in each county. 
Lastly, my regression equation incorporates metropolitan fixed effects by including dummy variables that represent the largest 100 metropolitan areas. This is to control for the potential correlations between counties within the same metropolitan areas. It also mitigates the potential bias from unobserved heterogeneities across metropolitan areas. Including metropolitan fixed effects, however, might capture some variation of income inequality at the county level, leading to a conservative estimate of the impact of inequality on rental affordability.

\section{Principal Component Analysis}

The Pearson correlation analyses show that several explanatory variables discussed above are highly correlated with each other, particularly those that represent the demographic characteristics of the studied counties. For example, large-sized counties tend to have higher proportions of young population and immigrants. Counties with higher unemployment rates also tend to have higher poverty rates. It would cause a multicollinearity problem and lead to unstable estimation results if I directly included these variables in the model. To avoid these problems, I conduct principal factor analyses (PCA) to reduce redundancy and minimize multicollinearity.

As shown in Table 2, I run PCA for all the nine variables that represent the socio-demographic characteristics of the studied counties in 2000 and 2008-2012 respectively. The PCA yields four extracted factors for the nine variables at each time point. The four extracted factors in 2000 explain $85 \%$ of the total variance of the nine variables; the four extracted factors in $2008-2012$ explain $83 \%$ of the total variance of the nine variables. In 2000, Factor A1 mainly represents three strongly correlated variables: total population, the share of young population, and the share of immigrants. A higher score on Factor A1 indicates larger population sizes and higher shares of young and immigrant population. Factor A2 mainly represents the shares of Black population, 
poverty rates, and unemployment rates. A higher score on Factor A2 is associated with a greater share of Black population, a higher poverty rate, and a higher unemployment rate. Factor A3 is mainly extracted from the two variables that represent the age structure of the population: the shares of baby-boomers and small households. A higher score of Factor A3 indicates greater shares of baby-boomers and small households. Factor 4 mainly represents the share of Hispanic population and is positively associated with it. In 2008-2012, Factor B1 mainly represents population sizes and the shares of immigrants and Hispanic population. Factor B2 is extracted from two variables that represent poverty rates and unemployment rates. Factor B3 represents the shares of baby-boomers and small households. Factor B4 indicates the shares of Generation Y and Black population.

Before proceeding to present my modeling analyses, it is important to note that the model results regarding the effect of income inequality on rental affordability from this study may be considered conservative estimates for at least two reasons. First, as aforementioned, all the models control for metropolitan fixed effects, which might also account for some variation of income inequality between counties. Second, some other explanatory variables (e.g. poverty rate) may also capture some variation of income inequality as both of them are related to income distribution in a place. The OLS models might not be able to completely disentangle the influences of these variables.

[Table 2 about here] 


\section{Modeling the Impact of Income Inequality on Rental Affordability}

\section{Cross-sectional Analysis}

I first conduct cross-sectional analyses to test the association between income inequality and the rates of severe rent burdens among low-income households in 2000 and 2008-2012. The two ordinary least squared (OLS) models in Table 3 show that there is a significant association between income inequality and rental unaffordability in both 2000 and 2008-2012, after controlling for the metropolitan fixed effects. A simple OLS model, however, may also pick up a reversed causal effect as housing affordability can also contribute to income inequality through homeownership (Dietz and Haurin, 2003). I thus develop two two-stage instrument variable (IV) estimators to test the existence of endogeneity.

\section{[Table 3 about here]}

A valid instrument must be correlated with the suspected endogenous variable and orthogonal to the error term in the regression. Following previous studies (Leigh, 2006; You and Khagram, 2005), we use the relative size of the cohort $40-59$ years of age in adult population (mature cohort size) in 2000 as an instrument variable for income inequality in 2000 and 2008-2012. The "mature cohort size" is a powerful predictor of income inequality because workers aged 40-59 tend to get low rewards, and when they lie at the top of the age-earning curve, earning inequality is reduced (Higgins and Williamson, 1999). The mature cohort size in a society, however, is unlikely to be determined by the rates of rent-burdened low-income households.

As shown in Table 3, the effects of income inequality on rent burdens remain statistically significant after controlling for the potential endogeneity problem in both 2000 and 2008-2012. The diagnostics of the instrument variable yield quite consistent results in the two two-stage IV 
models. First, it confirms that the correlation between the instrument and the suspected endogenous variable is sufficiently strong. Second, it indicates that the two-stage IV models are just as consistent as the OLS models. In general, these tests suggest that endogeneity should not be a concern in this analysis. This is not surprising because this study focuses on tenant households who do not own homes. Moreover, the study period is relatively short (less than 10 years) for homeownership to exert a significant effect on income inequality. Because OLS models are more efficient, I decide to stick to the OLS regression method in the following analyses.

\section{[Table 4 about here]}

In the two models presented in Table 4, I include more control variables that represent factors on the demand- and supply-sides of the rental market. The Pearson correlation analyses show that the variables that represent median rents and median incomes are highly correlated in $2000(\mathrm{r}=$ $0.81, \mathrm{p}<0.01)$ and $2008-2012(\mathrm{r}=0.77, \mathrm{p}<0.01)$. When both of them are included in the model, median rent is always statistically significant while median income is not. I thus include median rent only in the model. As explained earlier, I use the extracted factors from PCA (Table 2) to represent the socio-demographic characteristics of the studied counties. I also include rental vacancy rates to represent how tight local rental markets are. In the 2008-2012 model, I include a variable that measure the depth of the 2008 housing crisis. Both models control for the metropolitan fixed effects.

The model results show that income inequality yields positive and significant coefficients in both models. Everything else equal, an increase of Gini coefficient by 0.1 is associated with 2.2 and 4.4 percentage points more severely rent-burdened low-income households in 2000 and 2008- 
2012 respectively. As expected, counties with higher median rents are associated with higher rates of severely rent-burdened low-income households. Three of the four extracted factors are statistically significant in 2000. The model results of these three variables suggest that in 2000 , counties tended to have more severely rent-burdened households when they had larger population, greater shares of young population, immigrants, Black population, baby-boomers and smalls-sized households, as well as higher poverty and unemployment rates. The share of Hispanic population was not a significant predictor of server rent burdens for low-income households in 2000. In the 2008-2012 model, two of the four extracted factors are statistically significant. Their model results indicate that counties tended to have more severely rentburdened low-income households when they had greater shares of young population, Black population, small-sized households, and baby-boomers.

\section{Longitudinal Analysis}

The cross-sectional analyses discussed above reveal a strong association between income inequality and rent burden. However, cross-sectional analyses may not provide definite information about cause-and-effect relationships between the two variables. In order to further explore the causal effect of income inequality on rental affordability, I conduct longitudinal analyses by examining how the changes of income inequality affect the changes of rent burdens.

\section{[Table 5 about here]}

Table 5 presents the results of the longitudinal model. Unlike the cross-sectional models that use extracted factors, the longitudinal model uses the changes of individual control variables because the correlations between the changes of these variables are generally weaker. The model results show that the changes of income inequality had a significant effect on the changes of the rates of 
severely rent-burdened households from 2000 to 2008-2012, after controlling for the changes of many other relevant variables. This confirms that rising inequality did lead to worsening rental affordability for low-income households. Everything else equal, counties that saw a 0.1 more increase in Gini coefficient from 2000 to 2008-2012 experienced faster growth of the rates of severely rent-burdened low-income tenants by 2.9 percentage points.

The results of the control variables are consistent with expectations. A faster increase of median rent led to worsening rental affordability. Rent burdens became significantly worse in counties that saw faster growth in population, poverty rates, young population, and baby-boomers. Housing supply elasticity and the depth of recession are not significant predictors of the changes of the rates of severely rent-burdened low-income households.

\section{Conclusion and Policy Implication}

This study examines the effect of income inequality on rental affordability for low-income households in the counties within America's largest 100 metropolitan areas. We develop two cross-sectional models based on the data in 2000 and 2008-2010 respectively. We also conduct longitudinal analyses to evaluate how the changes of income inequality influence the changes of rental affordability for low-income tenant households. The cross-sectional models reveal a significant and consistent association between income inequality and the rate of severely rentburdened low-income households in both 2000 and 2008-2012, after controlling for many other demand- and supply-side factors. Everything else equal, an increase of Gini coefficient by 0.1 in a county was associated with 2.2 and 4.4 percentage points more severely rent-burdened lowincome households in 2000 and 2008-2012 respectively. The results of the longitudinal analyses confirm that the changes of income inequality have a significant effect on the changes of rental 
affordability, after controlling for the changes of other variables. On average, counties that experienced a 0.1 greater increase in Gini coefficient from 2000 to 2008-2012 saw faster growth of the rate of severely rent-burdened low-income households by 2.9 percentage points.

The past decade has seen a fast growing body of research suggesting that housing supply constraints caused by land use regulations are responsible for worsening home affordability in large American metropolitan areas, as discussed in the literature review section. It is widely believed that the removal of regulatory barriers will effectively improve housing affordability in American metropolitan. "To the extent that a city makes it easy for any type of housing to be built, it will also enhance the available stock of low-cost housing" (Malpezzi and Green, 1996). This study, however, did not find a significant and consistent effect of housing supply constraints on rental burdens of low-income households in large American metropolitan areas. This is probably because in places with high levels of inequality, filtering is not working effectively to increase the supply of affordable housing units for low-income households (Skaburskis, 2006). Furthermore, conspicuous housing consumption inspired by top income earners has pushed residential developers to build larger homes, making them less affordable. The median size of a new home in the United States in 2015 is 2,467 square feet, $61 \%$ bigger than 40 years ago (Sparshott, 2016), despite stagnant low- and middle-class incomes and declining family sizes. While the growing size and quality of new homes mean more and better housing services per dwelling unit, they are also reducing housing choices that are available for low-income households and forcing them to spend greater shares of their limited income on housing. This is probably why HUD's 2011 report found that inadequate housing caused only three percent of worst case needs while the vast majority of renters had worst case needs because of severe rent burdens. Therefore, simply removing regulatory barriers may not benefit low-income tenant 
households if home developers continue to focus on luxury homes. In order to meet the housing needs of low- and middle-income households, the goal of liberalizing land use regulations should be to allow and encourage developers to provide more diverse and affordable housing types.

This study also shows that many demand-side factors play important roles in determining home affordability, suggesting that housing policies and programs on the demand side cannot be ignored. Federal rental housing assistance programs have gradually shifted from project-oriented to tenant-oriented subsidies (Quigley and Raphael, 2004), but they still fall short of the total need of the nation by at least $40 \%$ (Landis, 2010). Given that the earnings of low-income households are unlikely to grow markedly and income inequalities are likely to keep rising in the foreseeable future, there is an urgent need to increase the priority and funding of rental assistance to lowincome tenants.

Acknowledgement: The author would like to thank the editor and anonymous reviewers for their review and comments. He would also like to thank the participants of the $10^{\text {th }}$ IACP conference for their comments on the preliminary results of this study. He is grateful for the Provost Faculty Scholarship Support Program at the California State University, Fresno for providing assigned time for this study. 


\section{Reference}

Arnold, E., and Skaburskis, A. (1989). Measuring Ontario's increasing housing affordability problem. Social Indicators Research, 21: 501-515.

Attanasio, O., Hurst, E., and Pistaferri, L. (2012). The evolution of income, consumption, and leisure inequality in the U.S., 1980-2010. NBER Working Paper No. 17982. Retrieved from http://www.nber.org/papers/w17982

Beitel, K. (2007). Did overzealous activities destroy housing affordability in San Francisco? A time-series test of the effects of rezoning on construction and home prices, 1967-1998. Urban Affairs Review, 42(5): 741-756.

Berube, A., and Holmes, N. (2015). Some cities are still more unequal than others-an update. Metropolitan Policy Program at Brookings. Retrieved from

https://www.brookings.edu/research/some-cities-are-still-more-unequal-than-others-an-update/

Berube, A., and Holmes, N. (2016). City and metropolitan inequality on the rise, driven by declining incomes. Metropolitan Policy Program at Brookings. Retrieved from http://www.brookings.edu/research/papers/2016/01/14-income-inequality-cities-update-berube$\underline{\text { holmes }}$

Bogdon, A.S., and Can, A. (1997). Indicators of local housing affordability: comparative and spatial approaches. Real Estate Economics, 25(1): 43-80.

Bramley, G. (2012). Affordability, poverty and housing need: triangulating measures and standards. Journal of Housing and the Built Environment, 27: 133-151.

Bunting, T., Walks, R.A., and Filion, P. (2004). The Uneven Geography of housing affordability stress in Canadian metropolitan areas. Housing Studies, 19(3): 361-393.

Comprehensive Housing Affordability Strategy (CHAS) Database. (2000). Retrieved from https:/www.huduser.gov/portal/datasets/cp2000.html

Comprehensive Housing Affordability Strategy (CHAS) Database. (2008-2012). Retrieved from https://www.huduser.gov/portal/datasets/cp/CHAS/data download chas.html

Clark, W.A.V., Deurloo, M.S., Dieleman, F.M. (2000). Housing consumption and residential crowding in U.S. housing markets. Journal of Urban Affairs, 22(1): 49-63.

Collinson, R. (2011). Rental housing affordability dynamics, 1990-2009. Cityscape, 13(2): 71103.

Dewilde, C., and Lancee, B. (2013). Income inequality and access to housing in Europe. European Sociological Review, 29(6): 1189-1200. 
Dougherty, C. (2016, April 16). In cramped and costly Bay Area, cries to build, baby, build. The New York Times. Retrieved from http://www.nytimes.com/2016/04/17/business/economy/sanfrancisco-housing-tech-boom-sf-barf.html

Frank, R. H. (2007). Falling behind: how rising inequality harms the middle class. University of California Press, Berkeley.

Dietz, R.D., and Haurin, D.R. (2003). The social and private micro-level consequences of homeownership. Journal of Urban Economics, 54: 401-450.

Glaeser, E. and Gyourko, J. (2003). The impact of building restrictions on housing affordability. Economic Policy Review, 9(2): 21-39.

Glaeser, E., Gyourko J. and Saks, R. (2005a). Why have housing prices gone up? American Economic Review, 95(2): 329-333.

Glaeser, E., Gyourko J. and Saks, R. (2005b) Why is Manhattan so expensive? Regulation and the rise of housing prices. Journal of Law and Economics, 48(2): 331-369.

Green, R., Malpezzi, S., and Mayo, S. (2005). Metropolitan-specific estimates of the price elasticity of supply of housing, and their sources. American Economic Review, 95(2): 334-339.

Greenwood, D.T., and Holt, R.P.F. (2010). Growth, inequality and negative trickle down. Journal of Economic Issues, 44(2): 403-410.

Gyourko, J., Mayer, C., and Sinai T. (2013) Superstar cities. American Economic Journal: Economic Policy, 5(4): 167-199.

Higgins, Matthew and Jeffrey G. Williamson. (2002). Explaining Inequality the World Round: Cohort Size, Kuznets Curves, and Openness. Southeast Asian Studies, 40(3): 268-302.

HUD. (2011). Worst Case Housing Needs 2009 (Report to Congress). Washington, D.C.

HUD. (2013). Worst Case Housing Needs 2011 (Report to Congress). Washington, D.C.

Ihlanfeldt, K. (2007). The effect of land use regulation on housing and land prices. Journal of Urban Economics, 61: 420-435.

Landis, J. (2010). Rethinking federal housing policy. Journal of the American Planning Association, 76(3): 319-348.

Leigh, A. (2006). Does Equality lead to fraternity? Economic Letters, 93(1): 121-125.

Kirkham, C. (2016, May 7). Home builders say they are squeezed by rising compliance costs. The Wall Street Journal. Retrieved from http://www.wsj.com/articles/home-builders-say-theyare-squeezed-by-rising-compliance-costs-1462613401 
Malpezzi, S., and Green, R.K. (1996). What has happened to the bottom of the US housing market. Urban Studies, 33(10): 1807-1820.

Matlack, J.L., and Vigdor, J.L. (2008). Do rising tides lift all boats? Income inequality and housing affordability. Journal of Housing Economics, 17: 212-224.

Moore, E., and Skaburskis, A. (2004). Canada's increasing housing affordability burdens. Housing Studies, 19(3): 395-413.

Moos, M., and Skaburskis, A. (2010). The globalization of urban housing markets: immigration and changing housing demand in Vancouver. Urban Geography, 31(6): 724-749,

Peters, M. (2016, April 24). How to make city housing more affordable. The Wall Street Journal. Retrieved from http://www.wsj.com/articles/how-to-make-city-housing-more-affordable$\underline{1461550190}$

Paciorek, A. (2013) Supply constraints and housing market dynamics. Journal of Urban Economics, 77: 11-26.

Piketty, T., and Saez, E. (2006). The Evolution of Top Incomes: A Historical and International Perspective. American Economic Review, 96(2): 200-205.

Quigley, J.M., and Raphael, S. (2004). Is housing unaffordable? Why isn't it more affordable? Journal of Economic Perspectives, 18(1): 191-214.

Skaburskis, A. (2006). Filtering, city change and the supply of low-priced housing in Canada. Urban Studies, 43(3): 533-558.

Saiz, A. (2007). Immigration and housing rents in American cities. Journal of Urban Economics, 61: $345-371$.

Stone, M.E. (2006). What is housing affordability? The case for the residual income approach. Housing Policy Debate, 17(1): 151-184.

S\&P Dow Jones Indices LLC, S\&P/Case-Shiller U.S. National Home Price Index C [CSUSHPINSA], retrieved from FRED, Federal Reserve Bank of St. Louis; https://fred.stlouisfed.org/series/CSUSHPINSA, February 3, 2017.

Sparshott, J. (2016, June 2). U.S. houses are still getting bigger. The Wall Street Journal. Retrieved from http://blogs.wsj.com/economics/2016/06/02/u-s-houses-are-still-getting-bigger/

Timiraos, N. (2015, November 20). Why White House Economists worry about land-use regulations. The Wall Street Journal. Retrieved from http://blogs.wsj.com/economics/2015/11/20/why-white-house-economists-worry-about-land-useregulations/ 
You, J.S., and Khagram, S. (2005). A comparative study of inequality and corruption. American Sociological Review, 70(1): 136-157.

Withers, S.D. (1997). Demographic polarization of housing affordability in six major United States metropolitan areas. Urban Geography, 18(4): 296-323. 
List of Tables and Figures:

Table 1. Descriptive statistics of the variables and their changes

Table 2. Principal component analysis

Table 3. Results of the two-stage IV models

Table 4. Results of the cross-sectional models

Table 5. Results of the longitudinal model

Figure 1. Income inequality and rate of severe rent-burdens among low-incomes at the county level within America's largest 100 metropolitan areas 
Table 1. Descriptive statistics of the variables and their changes

\begin{tabular}{|c|c|c|c|c|c|c|c|c|c|}
\hline variable & & 2000 & & & $008-201$ & & change & $\mathrm{m} 2000$ & $008-12$ \\
\hline & $\min$. & $\max$. & mean & $\min$. & $\max$. & mean & $\min$. & $\max$. & mean \\
\hline rent burden $(\%)$ & 9.98 & 41.71 & 23.82 & 12.04 & 52.71 & 34.50 & -5.70 & 31.03 & 10.68 \\
\hline Gini coefficient & 0.33 & 0.60 & 0.42 & 0.34 & 0.60 & 0.43 & -0.08 & 0.06 & 0.01 \\
\hline med. income (\$1000/\%) & 24.86 & 82.93 & 46.39 & 31.60 & 122.07 & 58.81 & -10.31 & 62.63 & 21.27 \\
\hline median rent $(\$ 1000 / \%)$ & 0.32 & 1.19 & 0.59 & 0.51 & 1.68 & 0.89 & -0.05 & 1.10 & 0.44 \\
\hline population (in $100,000 / \%$ ) & 0.16 & 95.19 & 3.57 & 0.20 & 98.40 & 3.97 & -29.56 & 109.42 & 15.95 \\
\hline poverty rate $(\%)$ & 2.24 & 31.87 & 9.82 & 3.00 & 31.95 & 11.87 & -6.93 & 9.23 & 2.05 \\
\hline Generation Y (\%) & 8.40 & 25.39 & 13.83 & 7.16 & 27.70 & 12.64 & -6.26 & 2.96 & -1.19 \\
\hline baby-boomers (\%) & 10.78 & 44.25 & 20.41 & 12.77 & 46.61 & 24.91 & -3.79 & 15.83 & 4.49 \\
\hline small households (\%) & 35.71 & 76.18 & 56.19 & 38.65 & 77.53 & 59.43 & -4.33 & 10.50 & 3.24 \\
\hline Black population (\%) & 0.03 & 78.57 & 11.22 & 0.07 & 79.33 & 11.99 & -9.08 & 27.17 & 0.77 \\
\hline Hispanic population (\%) & 0.33 & 88.35 & 7.39 & 0.34 & 90.62 & 10.36 & -3.55 & 16.38 & 2.97 \\
\hline immigrants (\%) & 0.07 & 19.26 & 2.78 & 0.00 & 15.37 & 2.72 & -6.65 & 3.75 & -0.07 \\
\hline unemployment (\%) & 1.73 & 14.33 & 4.95 & 3.22 & 17.92 & 8.86 & -6.22 & 11.51 & 3.91 \\
\hline rental vacancy $(\%)$ & 1.04 & 22.75 & 7.12 & 0.08 & 33.66 & 7.31 & & -- & \\
\hline recession & & -- & & 0.74 & 2.04 & 1.01 & & -- & \\
\hline supply elasticity & & -- & & & -- & & -9.19 & 8.98 & 0.53 \\
\hline $\mathrm{N}$ (counties) & & 507 & & & 507 & & & 507 & \\
\hline
\end{tabular}

Note: The change of Gini coefficient is calculated as the difference between 2000 and 2008-2012. When a variable is measured in percentage, its change is also calculated as the difference between 2000 and 2008-2012. Otherwise, the change is calculated as a percentage number through the formula (X2012 - X2000)/X2000*100. 
1

2

3

4

5

6

7

8

9

10

11

12

13

14

15

16

17

18

19

20

21

22

23

24

25

26

27

28

29

30

31

32

33

34

35

36

37

38

39

40

41

42

43

44

45

46

47

48

49

50

51

52

53

54

55

56

57

58

59

60
Table 2. Principal component analysis

2000

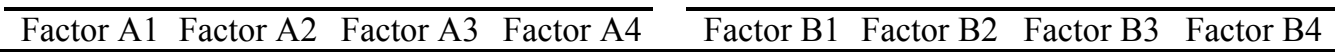

Ln(population) 0.82 0.85

Generation Y

0.76

immigrants

0.87

0.88

0.76

0.68

poverty rate

0.93

0.88

0.89

0.89

0.91

0.86

small households

0.77

0.77

$85.43 \%$

total variance explained

malization.

Note 2: rotated factor with loadings less than 0.5 are not presented. 
Table 3. Two-stage IV models

\begin{tabular}{|c|c|c|c|c|c|c|c|c|}
\hline \multirow[b]{4}{*}{ Variable } & \multicolumn{8}{|c|}{$\mathrm{DV}=$ rate of severe rent burdens among low-incomes $(\%)$} \\
\hline & \multicolumn{4}{|c|}{2000} & \multicolumn{4}{|c|}{$2008-2012$} \\
\hline & \multicolumn{2}{|c|}{ OLS } & \multicolumn{2}{|c|}{ two-stage IV } & \multicolumn{2}{|c|}{$\overline{\mathrm{OLS}}$} & \multicolumn{2}{|c|}{ two-stage IV } \\
\hline & Coef. & t-value & Coef. & t-value & Coef. & t-value & Coef. & t-value \\
\hline Gini coefficient & $51.60^{* *}$ & 9.74 & $64.71^{* *}$ & 5.25 & $51.48^{* *}$ & 6.88 & $50.47^{* *}$ & 2.96 \\
\hline Metropolitan fixed effects & \multicolumn{2}{|c|}{ yes } & \multicolumn{2}{|c|}{ yes } & \multicolumn{2}{|c|}{ yes } & \multicolumn{2}{|c|}{ yes } \\
\hline Constant & 3.68 & 1.04 & -1.96 & -0.33 & $16.53 * *$ & 3.32 & $16.98^{*}$ & 2.00 \\
\hline adjusted R squared & & & & & & & & \\
\hline \multirow[t]{3}{*}{$\mathrm{N}$} & & & & & & & & \\
\hline & \multicolumn{8}{|c|}{ IV diagnostics } \\
\hline & & & statistic & p-value & & & statistic & p-value \\
\hline Weak instruments & -- & -- & 93.74 & 0.00 & -- & -- & 96.56 & 0.00 \\
\hline Wu-Hausman & -- & -- & 1.42 & 0.24 & -- & -- & 0.00 & 0.95 \\
\hline
\end{tabular}

Note: ${ }^{*} \mathrm{p}<0.05 ;{ }^{* *} \mathrm{p}<0.01$; Coef. $=$ coefficient; IV $=$ instrumental variable. 
Table 4. Cross-sectional models

\begin{tabular}{|c|c|c|c|c|}
\hline \multirow[b]{3}{*}{ Variable } & \multicolumn{4}{|c|}{$\begin{array}{c}\mathrm{DV}=\text { rate of severe rent burdens } \\
\text { among low-incomes }(\%)\end{array}$} \\
\hline & \multicolumn{2}{|c|}{2000} & \multicolumn{2}{|c|}{$2008-2012$} \\
\hline & Coef. & $\mathrm{t}$-value & Coef. & $\overline{\text { t-value }}$ \\
\hline$\overline{\text { Gini coefficient }}$ & $21.66^{* *}$ & 2.95 & $44.28^{* *}$ & 4.27 \\
\hline median rent & $28.07 * *$ & 10.50 & $23.82 * *$ & 8.34 \\
\hline Factor A1 & $0.78 * *$ & 3.21 & -- & -- \\
\hline Factor A2 & $1.67 * *$ & 5.40 & -- & -- \\
\hline Factor A3 & $0.82 * *$ & 2.90 & -- & -- \\
\hline Factor A4 & 0.39 & 1.19 & -- & -- \\
\hline Factor B1 & -- & -- & 0.00 & -0.01 \\
\hline Factor B2 & -- & -- & $0.99 *$ & 2.43 \\
\hline Factor B3 & -- & -- & -0.55 & -1.47 \\
\hline Factor B4 & -- & -- & $1.23 * *$ & 3.41 \\
\hline rental vacancy & 0.01 & 0.12 & 0.02 & 0.19 \\
\hline recession & -- & -- & 5.44 & 1.74 \\
\hline Metropolitan fixed effect & \multicolumn{2}{|c|}{ yes } & \multicolumn{2}{|c|}{ yes } \\
\hline Constant & 1.18 & 0.30 & -3.61 & -0.54 \\
\hline adjusted R squared & \multicolumn{2}{|c|}{0.69} & \multicolumn{2}{|c|}{0.63} \\
\hline $\mathrm{N}$ & \multicolumn{2}{|c|}{507} & \multicolumn{2}{|c|}{507} \\
\hline
\end{tabular}

Note: ${ }^{*} \mathrm{p}<0.05 ; * * \mathrm{p}<0.01 ;$ Coef. $=$ coefficient. 
Table 5. Longitudinal model

\begin{tabular}{lcc}
\hline & Coef. & t-value \\
\hline$\Delta$ Gini coefficient & $29.23^{*}$ & 1.98 \\
$\Delta$ median rent & $0.17^{* *}$ & 6.68 \\
$\Delta$ population & $0.06^{* *}$ & 3.18 \\
$\Delta$ poverty rate & $1.61^{* *}$ & 8.77 \\
$\Delta$ Generation Y & $0.58^{*}$ & 2.20 \\
$\Delta$ baby-boomers & $0.40^{*}$ & 2.08 \\
$\Delta$ small-sized households & -0.12 & -0.84 \\
$\Delta$ Blacks & 0.16 & 1.91 \\
$\Delta$ Hispanics & -0.16 & -1.01 \\
$\Delta$ immigrants & 0.40 & 1.66 \\
$\Delta$ unemployment rate & -0.23 & -1.51 \\
rental housing supply elasticity & -0.15 & -0.48 \\
recession & 1.07 & 0.34 \\
Metropolitan fixed effects & \multicolumn{2}{c}{ yes } \\
Constant & -2.23 & -0.50 \\
\hline adjusted R squared & \multicolumn{3}{c}{0.37} \\
$\mathrm{~N}$
\end{tabular}

Note: ${ }^{*} \mathrm{p}<0.05 ; * * \mathrm{p}<0.01 ;$ Coef. $=$ coefficient.

Note: dependent variable is the change of the rates of severe rent burdens among lowincome tenant households $(\%, 2000$ to 2008-2012) 

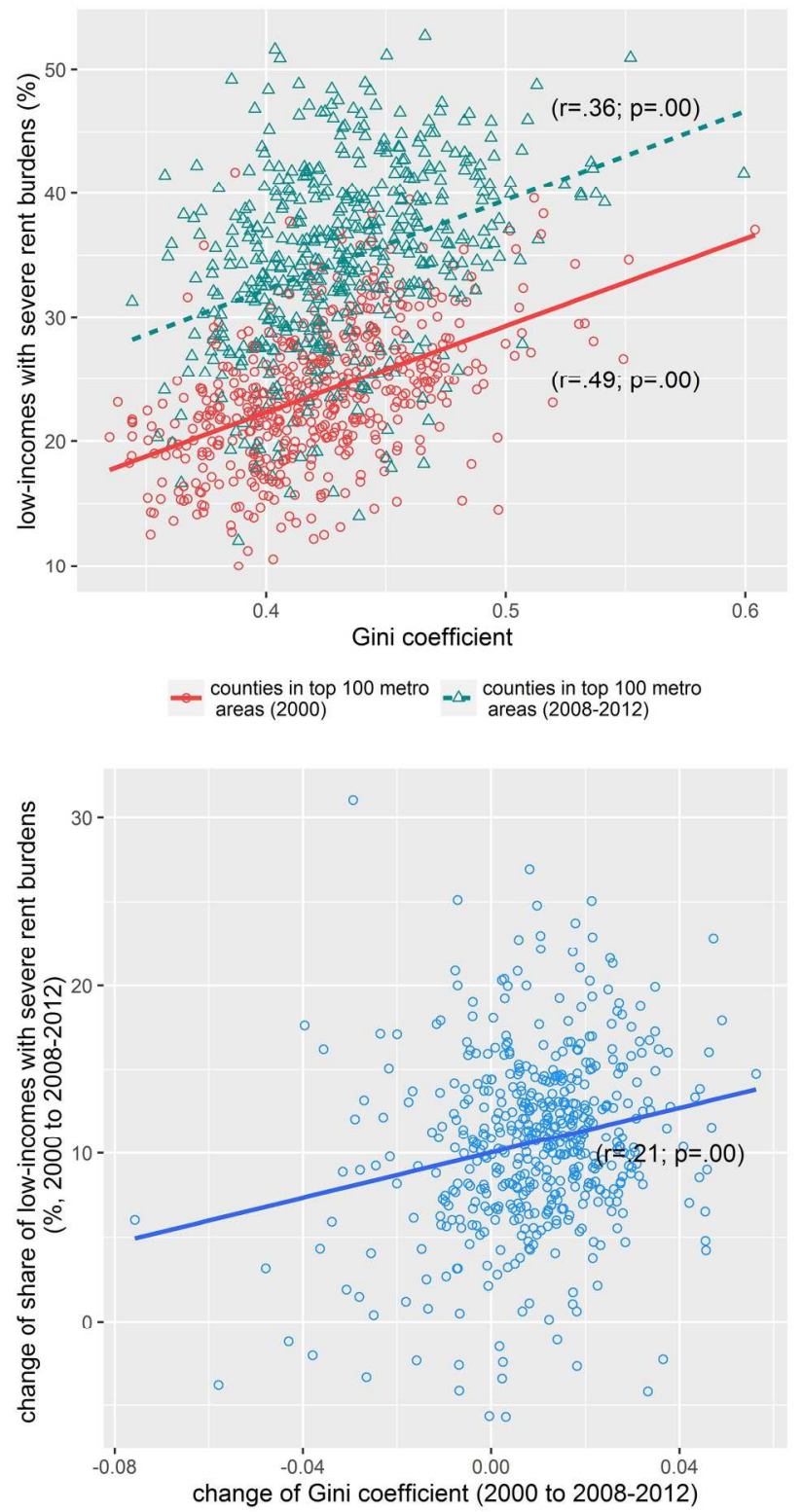

Figure 1. Income inequality and rate of severe rent-burdens among low-incomes at the county level within America's largest 100 metropolitan areas

$241 \times 458 \mathrm{~mm}(150 \times 150 \mathrm{DPI})$ 